\title{
PHYSICAL-CHEMICAL CHARACTERISTICS OF HERBICIDES USED FOR MAIZE PRODUCTION IN BIH AS FACTORS OF POTENTIAL HERBICIDE LEACHING IN GROUNDWATER
}

\author{
Siniša MITRIĆ ${ }^{1 *}$, Mihajlo MARKOVIĆ ${ }^{1}$, Mladen BABIĆ ${ }^{1}$, Milan ŠIPKA ${ }^{1}$, \\ Dušica PEŠEVIĆ ${ }^{2}$, Duško DRAGIČEVIĆ ${ }^{1}$
}

\begin{abstract}
The aim of the study is to present the elements which must be considered while determining the risk of the mobility of the herbicides. Herbicides used for maize production have the special eco toxical significance and special risk because some are potentially mobile, they are used on the large surfaces during the rainy period and near rivers.

Behaviour of the herbicides in the environment, particularly in the soil is very complex. It does not depend only on the characteristics of the herbicide, but on the many factors of the environment which are very variable. Regardless of this fact, there are experimentally determined physical-chemical indicators for each herbicide that show the possible behaviour of herbicides in the environment. Studied physical-chemical indicators of herbicide behavior are: Distribution Coefficient (Kd); Organic Carbon Partitioning Coefficient (Koc); Time of the Semi-Decomposition ( $\mathrm{DT}_{50}$ ); Water Solubility (S); Groundwater Ubiquity Score (GUS); Henry's Law Constant (Kh), Vapor Pressure (PV) and the Dissociation Constant $\left(\mathrm{pK}_{\mathrm{a}}\right)$.

Namely, herbicides, in larger or smaller measure, have "leaching potential", which is ability to reach the underground water. One of the basic criteria for evaluating the herbicide ability to reach the underground water is related to indicators of mobility and persistency $\left(\mathrm{DT}_{50}\right)$ herbicides, but neglecting some other criteria in that evaluation such as the amount of applying, characteristics of the soil and the aim of the crop growth. According to the EPA criteria, for the herbicides used in maize production in Bosnia

\footnotetext{
${ }^{1}$ University of Banja Luka, Faculty of Agriculture, Student city, Bulevar vojvode Petra Bojovića 1A, 78000 Banja Luka, Bosnia and Herzegovina

${ }^{2}$ University of Banja Luka, Faculty od Sciences, Mladena Stojanovica 2, 78000 Banja Luka, Bosnia and Herzegovina

*Corresponding author: sinisa.mitric@agrofabl.org
} 
and Herzegovina $(\mathrm{BiH})$, the "trigger" value will indirectly indicate if the herbicides have large leaching potential.

Keywords: herbicides, leaching, indicators, risk, maize

\section{INTRODUCTION}

Maize (Zea mays L.) is a plant that is grown on the largest agricultural area in the Bosnia and Herzegovina $(\mathrm{BiH})$ and Republic of Srpska compared to the other crops. Maize is grown on between 190,000 and 200,000 ha (Table 1) in the past years in $\mathrm{BiH}$. Majority of maize production of $\mathrm{BiH}$, between 140,000 and 150,000 ha each year, is in Republic of Srpska in the valley of Vrbas and Sava river. In these areas groundwater level is high and the risk of potentially contamination is more expressed. Paris et al. (2013) were doing monitoring of surface and groundwater in Italy and they found that herbicides, with the highest frequency in most of groundwater are: Terbuthylazine, Atrazine, Metolachlor and Bentazone.

Table 1. Area harvested (ha) cereals, total (Source: FAOSTAT)

\begin{tabular}{llrrrr}
\hline \multirow{2}{*}{ Countries } & \multirow{2}{*}{ Item } & \multicolumn{4}{c}{ Area harvested (ha) } \\
& & $\mathbf{2 0 1 0}$ & $\mathbf{2 0 1 1}$ & $\mathbf{2 0 1 2}$ & $\mathbf{2 0 1 3}$ \\
\hline \hline \multirow{3}{*}{$\begin{array}{l}\text { Bosnia and } \\
\text { Herzegovina }\end{array}$} & Barley & 18,637 & 20,745 & 20,453 & 20,678 \\
\cline { 2 - 6 } & Buckwheat & 553 & 584 & 564 & 633 \\
\cline { 2 - 6 } & Maize & $\mathbf{1 8 8 , 7 5 2}$ & $\mathbf{1 9 5 , 9 7 0}$ & $\mathbf{1 9 6 , 5 0 4}$ & $\mathbf{1 8 9 , 5 5 4}$ \\
\cline { 2 - 6 } & Oats & 9,958 & 10,007 & 10,280 & 9,838 \\
\cline { 2 - 6 } & Rye & 2,947 & 3,295 & 3,456 & 3,704 \\
& Triticale & 11,299 & 11,207 & 9,963 & 11,500 \\
& Wheat & 54,623 & 58,400 & 60,713 & 67,630 \\
\hline
\end{tabular}

Maize production in this area is characterized with intensive use of herbicides to combat weeds. Some of the herbicides that are used in large quantities are potentially very mobile, and in addition to the relatively high quantity and mobility, herbicides are used at the end of April and the first half of May, when the precipitation is high, presenting an additional factor that may contribute to the mobility and leaching of herbicide $\sin$ to river sand groundwater. On the other hand, Janjic et al. (2005) emphasize that the sulfonylurea herbicides, were less mobile in the soil and does not exist real risk of their leakage into groundwater. 


\section{MATERIAL AND METHODS}

In this study, physical-chemical characteristics of the herbicides used for corn production were analyzed. Those physical-chemical herbicide characteristics indicate partitioning behaviour and environmental persistence. Some of herbicides exceed the "trigger" value, and that indicate their possible mobility in the soil. Particularly important indicators of the herbicide behaviour in the soil are: Distribution Coefficient$\mathrm{Kd}\left(\mathrm{ml} \cdot \mathrm{g}^{-1}\right)$, The Organic Carbon Partitioning Coefficient-Koc $\left(\mathrm{ml} \cdot \mathrm{g}^{-1}\right)$, Time of the Semi-decomposition-DT $\mathrm{T}_{50}$ (days), Water Solubility-S (mg/L) and Groundwater Ubiquity Score (GUS).

Distribution coefficient $-\mathbf{K d ~}\left(\mathbf{m L} \cdot \mathbf{g}^{-1}\right)$. Distribution Coefficient is defined as the ratio of equilibrium concentrations $\mathrm{C}$ of a dissolved test substance in a two phase system consisting of a sorbent (soil or sewage sludge) and an aqueous phase; it is a dimensionless value when concentrations in both phases are expressed on a weight/weight base. In case the concentration in the aqueous phase is given on a weight/volume base then the units are $\mathrm{ml} \cdot \mathrm{g}^{-1}$. The $\mathrm{Kd}$ is relevant to understanding pesticide transport since chemicals remaining in soil solution can leach or become available in the water of a pond or stream. Because pesticides in soil solution are subject to leaching, the extent of sorption as measured by the $\mathrm{Kd}$ serves as a predictor of mobility: the higher the Kd, the lower the tendency to move in soil. For example, if a $\mathrm{Kd}$ is lower than 2, the molecule is termed highly mobile; if it's between 2 and 5 , the molecule is considered mobile; and if the $\mathrm{Kd}$ is greater than 5, it's deemed immobile with respect to leaching (Whitford et al.).

The Organic Carbon Water Partitioning Coefficient - Koc $\left(\mathbf{m L} \cdot \mathrm{g}^{-1}\right)$. For nonpolar pesticides, sorption is primarily related to associations with organic materials in the soil and sediments. A Koc value greater than 500 is usually associated with immobile pesticides (Wilson, 2009).

Time of the Semi-Decomposition - DT Do $_{\mathbf{5 0}}$ (days). Pesticide persistence often is expressed in terms of Time of the Semi-Decomposition in soil (see Table 2). This is the length of time required for one-half of the original quantity to break down (Kerle et al., 2007).

Table 2. Categories pesticides based Time of the Semi-Decomposition - $\mathrm{DT}_{50}$ (Kerle et al., 2007)

Categories based on half-lives

Non persistent pesticides

Moderately persistent pesticides

Persistent pesticides
Time of the Semi-Decomposition DT Do (days)

$<30$ days

30-100 days

$>100$ days 
Water Solubility- S (mg/L). Water Solubility describes the amount of pesticide that will dissolve in a known amount of water. It usually is measured in milligrams per litter of water $(\mathrm{mg} / \mathrm{L})$ or parts per million $(\mathrm{ppm})$.

Groundwater Ubiquity Score (GUS). The Groundwater Ubiquity Score, or GUS, frequently is used to rate pesticides for their potential to move toward groundwater (see Table 3.). The GUS is a number that relates pesticide persistence (Time of the SemiDecomposition - $\mathrm{DT}_{50}$ ) and Sorption (Koc) in soil (Gustafson, 1989).

$$
\text { GUS }=\log \left(D T_{50}\right) \times\left[4-\log \left(K_{O C}\right)\right]
$$

Table 3. Pesticide movement ratings and their GUS equivalents (Kerle et al., 2007)

\begin{tabular}{cc}
\hline GUS values & Pesticide Movement Rating \\
\hline$<0.1$ & Extremely low \\
$0.1-1.0$ & Very low \\
\hline $1.0-2.0$ & Low \\
\hline $2.0-3.0$ & Moderate \\
$3.0-4.0$ & High \\
\hline 4.0 & Very high \\
\hline
\end{tabular}

Screening Pesticides for Potential to Leach into Ground Water- Trigger Values. Trigger values are based strictly on laboratory data. Further refinements of ground water assessment of the pesticide should consider additional field parameters such as application rate, soil, and target crops. Trigger values are determined from a group of reference pesticides which have a history of use and extensive ground water monitoring. The following values may be used by regulators as an initial step to identify pesticides most likely to leach to ground water (Whitford et al., 1996):

\section{Trigger Values Related to Persistence:}

1. Aerobic soil metabolism half-life of greater than two to three weeks;

2. Field dissipation half-life of greater than two to three weeks;

3. Photolysis half-life greater than one week; or

4. Hydrolysis half-life greater than 60 days in sterile water.

\section{Trigger Values Related to Mobility:}

1. Koc usually less than 300 ;

2. The pesticide is a weak to moderate acid which would not be attracted to most soil particles; or

3. Water solubility greater than 30 parts per million (ppm). 


\section{The Groundwater Ubiquity Score:}

1. GUS greater than 2.8 are more likely to leach to ground water;

2. While those with GUS values between 1.8 and 2.8 are somewhat less likely to leach;

3. Pesticides with GUS values less than 1.8 are unlikely to leach to ground water.

Screening Pesticides for Runoff Potential - Trigger Values. Herbicides can arrive into the water also by the runoff. Three factors are important for the runoff: type of soil; slope of terrain; and the intensity and timing (with respect to pesticide application) of rainfall. In evaluating surface runoff potential, pesticides are assigned based on their half-lives and sorptive Koc (Whitford et al., 1996).

Sorptive Koc $\left(\mathrm{mL} \cdot \mathrm{g}^{-1}\right)$ :

1. Low sorption: Koc less than or equal to 1000 ;

2. Intermediate sorption: Koc greater than 1000 and equal to or less than 10,000;

3. High sorption: Koc greater than 10,000.

Persistence $\left(\mathrm{DT}_{50}\right)$ in Soil:

1. Short: Time of the Semi-Decomposition equal to or less than 2 weeks;

2. Intermediate Time of the Semi-Decomposition greater than 2 weeks but less than or equal to 2 months;

3. Long: Time of the Semi-Decomposition greater than 2 months.

\section{RESULTS}

Weed control in maize production in $\mathrm{BiH}$ is done with an herbicides application. Nonchemical approach to combat weeds in maize production are present in the mountainous regions, but there sporadically performed and in very small areas. Number of herbicide which is registered for application in maize production is enormous. The Table 4. below presents the review of commercial herbicides used in maize production in $\mathrm{BiH}$. 
Table 4. Review of the registrated herbicides for maize production in $\mathrm{BiH}$ (Official Gazette of BiH, No. 49/2004 and Official Gazette of the Republic of Srpska, No. 66/2014)

\begin{tabular}{|c|c|c|}
\hline ACTIVE INGREDIENT & $\begin{array}{l}\text { PRODUCT TRADE } \\
\text { NAME }\end{array}$ & $\begin{array}{c}\text { APPLICATION } \\
\text { TIME } \\
\text { Pre/Post Emergent } \\
\end{array}$ \\
\hline 2,4-D & Monosan herbi & Post EM \\
\hline 2,4- D + Floramsulam & Mustang & Post EM \\
\hline Bentazon & Basagran & Post EM \\
\hline Bentazon + Dicamba & Cambio & Post EM \\
\hline Clopyralid & Lontrel- 100 & Post EM \\
\hline Dicamba & Banvel 480- S & Post EM \\
\hline Dimethenamid-P & Frontier SUPER & Pre EM \\
\hline Dimetenamid+ Terbuthylazine & Akris & Pre/Post EM \\
\hline Flumioksazin & Pledge $50 \mathrm{WP}$ & Pre EM \\
\hline Fluroxypir meptyl & Starane 250 & Post EM \\
\hline Foramsulphurone + Izoxadiphen-etyl & Equip & Post EM \\
\hline $\begin{array}{l}\text { Foramsulphurone + Izoxadiphen-etyl + } \\
\text { Iodsulphuron-methyl sodium }\end{array}$ & Maister- OD & Post EM \\
\hline Isoxaflutole & Merlin $750 \mathrm{WG}$ & Pre/Post EM \\
\hline Isoxaflutole + Ciprosulfamid & Merlin flex & Pre EM \\
\hline Linuron & Linurex 50-WP & Pre EM \\
\hline Mesotrione & Callisto & Post EM \\
\hline Nicosulfuron & Motivell & Post EM \\
\hline Nicosulfuron + Rimsulfuron & Cordus $75-$ WG & Post EM \\
\hline Nicosulfuron + Sulcotrione & Talisman & Post EM \\
\hline Pendimethalin & Stomp 330-E & Pre EM \\
\hline Prosulfuron & Peak 75-WG & Post EM \\
\hline Prosulfuron + Dicamba & Casper 55 WG & Post EM \\
\hline Rimsulfuron & Tarot $25-\mathrm{WG}$ & Post EM \\
\hline Rimsulfuron + Dicamba & Tarot plus WG & Post EM \\
\hline Rimsulfuron + Thifensulfuron-methyl & Grid 75 WG & Post EM \\
\hline S-metolachlor + Terbuthylazine + Mesotrione & Lumax & Post EM \\
\hline S-metolachlor & Dual GOLD 960 EC & Post EM \\
\hline Sulcotrione & Tangenta & Post EM \\
\hline
\end{tabular}




\begin{tabular}{llc}
\hline ACTIVE INGREDIENT & $\begin{array}{c}\text { PRODUCT TRADE } \\
\text { NAME }\end{array}$ & $\begin{array}{c}\text { APPLICATION } \\
\text { TIME } \\
\text { Pre/Post Emergent }\end{array}$ \\
\hline \hline Tembotrione + Izoksadifen-etilen & Laudis & Post EM \\
\hline Terbuthylazine & Radazin TZ- 50 & Pre/Post EM \\
\hline Terbuthylazine + Bromoxynil & Zeagran 340- SC & Post EM \\
\hline Terbuthylazine + Isoxaflutole & Merlin DUO & Pre/Post EM \\
\hline Thifensulfuron-methyl & Harmony 75 WG & Post EM \\
\hline Topramezon & Clio & Post EM \\
\hline
\end{tabular}

Whereas maize is grown on large areas near rivers, where groundwater level is high, the potential mobility of herbicides used in the cultivation of maize is taken into consideration, and shown in Table 5. Characteristics of the herbicides which are used at corn according to the Partitioning Behaviour and Environmental Persistence and their "trigger" of the value are shown in Table 5.

Table 5. Physical and chemical properties of herbicides used in maize production (Source: EU Pesticides data base; EPA; EXTOXNET; PAN Pesticides Database-Chemicals; California Environmental Protection Agency and Cabrera, A. at al., 2007)

\begin{tabular}{|c|c|c|c|c|c|}
\hline Active Ingredient & CAS No & $\begin{array}{c}\mathrm{DT}_{50} \text { Soil } \\
\text { (days) }\end{array}$ & $\begin{array}{c}\text { Water solubility } \\
(\mathrm{mg} / \mathrm{L})\end{array}$ & $\begin{array}{c}\text { Koc } \\
\left(\mathbf{m l} \cdot \mathbf{g}^{-1}\right)\end{array}$ & $\begin{array}{c}\text { GUS* } \\
\text { (calculate } \\
\text { d) }\end{array}$ \\
\hline 2,4-D Acet Acid & $94-75-7$ & 20 & $\begin{array}{c}23180 \mathrm{mg} / \mathrm{L} \\
\left(\text { at } 25^{\circ} \mathrm{C} ; \mathrm{pH} 7\right)\end{array}$ & $5-212$ & $2.17-4.29$ \\
\hline Bentazone & $25057-89-0$ & $4-21$ & $\begin{array}{c}570 \mathrm{mg} / \mathrm{L} \\
\text { (at } 25^{\circ} \mathrm{C} ; \sim \mathrm{pH} \text { 7) }\end{array}$ & $13-176$ & $1.73-2.32$ \\
\hline Dicamba & 1918-00-9 & $7-28$ & $\begin{array}{c}6500 \mathrm{mg} / \mathrm{L} \\
\left(\text { at } 25^{\circ} \mathrm{C}\right)\end{array}$ & 31.6 & $2.10-3.63$ \\
\hline Dimethenamid-P & $163515-14-8$ & $4,7-16$ & $\begin{array}{l}1449 \mathrm{mg} / \mathrm{L} \\
\text { (at } 20^{\circ} \mathrm{C} \text { ) }\end{array}$ & $129-474$ & $1.26-3.21$ \\
\hline Linuron & $330-55-2$ & $13-82$ & $\begin{array}{c}63.8 \mathrm{mg} / \mathrm{L} \\
\left.\text { (at } 25^{\circ} \mathrm{C} ; \mathrm{pH} 7\right)\end{array}$ & $410-463$ & $1.54-2.54$ \\
\hline Mesotrione & $104206-8$ & $3-7$ & $\begin{array}{l}160 \mathrm{mg} / \mathrm{L} \\
\left(\text { at } 20^{\circ} \mathrm{C}\right)\end{array}$ & $29-390$ & $0.68-1.18$ \\
\hline Nicosulfuron & 111991-09-4 & 26 & $\begin{array}{l}70 \mathrm{mg} / \mathrm{L} \\
\left(\text { at } 20^{\circ} \mathrm{C}\right)\end{array}$ & $15.4-78.8$ & $2.96-3.96$ \\
\hline Pendimethalin & $40487-42-1$ & $27-186$ & $\begin{array}{c}0.33 \mathrm{mg} / \mathrm{L} \\
\text { (at } 20^{\circ} \mathrm{C} ; \mathrm{pH} \text { 7) }\end{array}$ & $\begin{array}{l}6,700- \\
29,400\end{array}$ & $-1.06-0.25$ \\
\hline Prosulfuron & $94125-34-5$ & $5-36$ & $\begin{array}{c}4000 \mathrm{mg} / \mathrm{L} \\
\text { (at } 25^{\circ} \mathrm{C} ; \mathrm{pH} 6.8 \text { ) }\end{array}$ & $4-41$ & $2.38-3.72$ \\
\hline Rimsulfuron & $122931-48-0$ & 21 & $\begin{array}{c}3750 \mathrm{mg} / \mathrm{L} \\
\left(\text { at } 20^{\circ} \mathrm{C} \text { ) }\right.\end{array}$ & 49 & 3.04 \\
\hline \multirow{2}{*}{ S-metolachlor } & (S-isomer) 87392-12-9 & \multirow{2}{*}{$11-31$} & \multirow{2}{*}{$\begin{array}{c}480 \mathrm{mg} / \mathrm{L} \\
\text { (at } 25^{\circ} \mathrm{C} ; \mathrm{pH} 7.3 \text { ) }\end{array}$} & \multirow{2}{*}{$110-369$} & \multirow{2}{*}{$2.04-2.13$} \\
\hline & (R-isomer) $178961-20-1$ & & & & \\
\hline
\end{tabular}




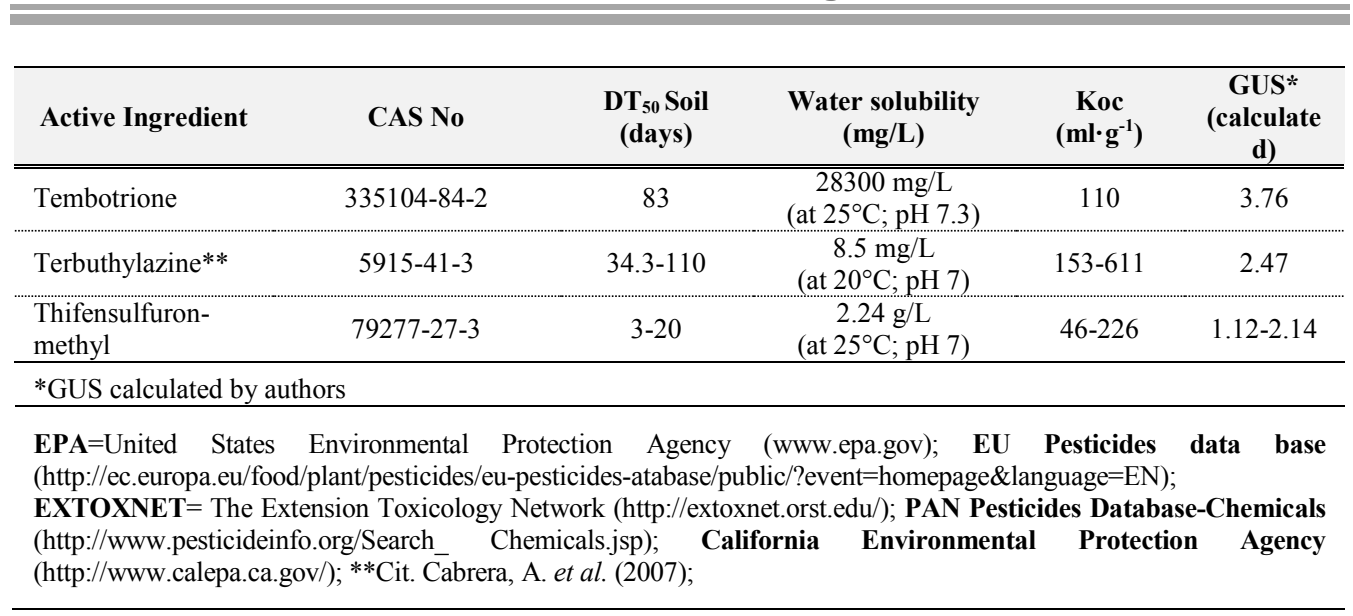

\section{DISCUSSION}

Analysis of the physical-chemical characteristics of the herbicides that are used for maize production and their comparison with the "trigger" value which point at potential to leach into groundwater indicate that Bentazone, Linuron, Nicosulfuron, Pendimethalin, Rimsulfuron, S-metolachlor, Tembotrione, Terbuthylazine have or can have Time of the Semi-Decomposition (DT50) in aerobic soil conditions longer than two or three weeks. If we observe water solubility and consider that trigger values related to mobility is greater than 30 parts per million (ppm), then almost all herbicides used for maize production, besides Pendimethalin, Terbuthylazine and Thifensulfuron-methyl satisfy this value. If we take value Koc $\left(\mathrm{mL} \cdot \mathrm{g}^{-1}\right)$, and as "trigger" values usually less than 300 , we conclude that most herbicides which are used for maize production have Koc $<300$. If theGUS valueis greater than 2.8 , it is more likely that herbicides will leach to ground water, and that value can occur for: 2,4-D Acet Acid, Dicamba, Dimethenamid-P, Prosulfuron, and it is always achieve for Nicosulfuron (GUS=2.96-3.96), Rimsulfuron (GUS=3.04) and Tembotrione (GUS=3.76).

\section{CONCLUSIONS}

The largest areas under the maize production in $\mathrm{BiH}$ are near river valleys where the herbicides are used for weed control.

Physical-chemical characteristics of the herbicides that are used for maize production and their comparison with the "trigger" value, indicate that the possibility of groundwater contamination exists. 
Our research indicate that it is necessary to conduct: Special Studies to Evaluate Leaching Potential, Screening Pesticides for Runoff Potential, Assessment of Runoff Potential, Surface Water Contamination and Spray Drift Studies. Therefore, it is necessary to develop a public policy and strategy for soil and water protection through the controlled and restricted use of herbicides.

\section{REFERENCES}

Cabrera, A.; Cox, L.; Velarde, P.; Koskinen, C.W.; Cornejo, J. 2007. Fate of Diuron and Terbuthylazine in Soils Amended with Two-Phase Olive Oil Mill Waste. J. Agric. Food Chem. 55, 4828-4834.

FAOSTAT .www.faostat.org

Federal Hydrological Service. http://www.fhmzbih.gov.ba/latinica/HIDRO-WWD09.php

Gustafson, D.I. 1989. Groundwater ubiquity score: a simple method for assessing pesticide leachability. Environmental Toxicology and Chemistry 8, 339-357.

Janjić, V., Đalović, I., Mitrić, S. 2005. Behaviour and degradation in soil of herbicide inhibitor of acetolactate-synthase. Herbologija, Vol. 6, No. 1, 91-102.

Kerle, A.E., Jenkins, J.J., Vogue, A.P. 2007. Understanding pesticide persistence and mobility for groundwater and surface water protection. Oregon State University, Extension Service, EM 8561-E (http://extension.oregonstate.edu /catalog/html/ em/em8561-e/).

Paris, P.; Citro, L.; Di Carlo, E.; Maschio, G., Pace, E.; Ursino, S. 2013: Rapporto nazionale pesticidi nelle aque dati 2009-2011- Edizione 2013. ISPRA- Istituto Superiore per la Protezione e la Ricerca Ambientale (ISBN 978-88-448-0595-1), p. 1-81.

Whitford, F., Wolt, J., Nelson, H., Barrett, M., Brichford, Sarah, Turco, R. 2002. Pesticides and water quality- principles, policies, and programs. Purdue university cooperative extension service, West Lafayette, IN 47907 (https://ag.purdue.edu/ btny/Extension/Pages/PPP.aspx)

Wilson, C. 2009. Aquatic Toxicology Notes: Predicting the Fate and Effects of Aquatic and Ditchbank Herbicides. Florida Cooperative Extension Service, Institute of Food and Agricultural Sciences, University of Florida, SL236 (http://edis.ifas.ufl.edu.) 